Check for updates

The BMJ

fgodlee@bmj.com Follow Fiona on Twitter @fgodlee

Cite this as: BMJ 2020;371:m4764 http://dx.doi.org/10.1136/bmj.m4764 Published: 10 December 2020

\title{
Covid-19: Transparency and communication are key
}

\section{Fiona Godlee editor in chief}

As the first wave of covid-19 vaccination gets under way, the need for good communication has never been greater. Without it, the extraordinary scientific advances that have led to the vaccines' development might easily be derailed. Clumsy political jingoism almost hijacked the UK's rapid approval of the Pfizer vaccine. But the regulator has made it clear that, despite giving emergency temporary authorisation, all the usual procedures were followed. ${ }^{1}$

Now we need to make sure that the vaccination programme is implemented well, say Azeem Majeed and Mariam Molokhia, avoiding the "many mistakes made during other components of the government's response" to the pandemic. ${ }^{2}$ Given that this has to be delivered alongside an expanded flu vaccination programme, ${ }^{3}$ primary care must be properly funded, with special attention to protecting those most vulnerable to infection. ${ }^{4}$ Internationally it also means ensuring fair allocation and equitable distribution. ${ }^{5}$

Legitimate questions about the vaccines will continue, ${ }^{6}$ even after the phase III results are released. ${ }^{7}$ So too will questions about how governments are making decisions. The UK's National Audit Office has been highly critical of cronyism, saying that in times of crisis it's even more important to have a clear approach to managing conflicts of interest. But Paul Thacker has found the financial ties of government advisors hard to uncover. ${ }^{8}$ The membership of the UK Scientific Advisory Group for Emergencies (SAGE) was released only after media pressure. Sadly, the same looks likely to be true for members' financial interests.

As for what the UK can learn from Slovakia's mass asymptomatic testing programme, the answer is not much, say Martin McKee and Iveta Nagyova. ${ }^{9}$ That's a shame, because confusion continues to surround the mass testing in Liverpool. As more data emerge on the rapid test's low sensitivity, ${ }^{10}$ the programme's always uncertain purpose has shifted: away from identifying people who aren't infected and onto finding those who are. But at what cost, asks Mike Gill, ${ }^{11}$ and where is the research and regulatory oversight?

Decisions in this pandemic must be made at speed and amid great uncertainty. All the more need for proper process, transparency, and good communication.

\section{The BMJ Appeal 2020-21}

Contributions to this year's appeal have been pouring in. Your support for the Independent Food Aid Network means more help for hard pressed families this covid winter. ${ }^{12} 13$ Thank you. Please keep it coming.

Mahase E. Vaccinating the UK: how the covid vaccine was approved, and other questions answered. BM/2020;371:m4759doi: 10.1136/bmj.m4759.
2 Majeed A, Molokhia M. Vaccinating the UK against covid-19. BMJ 2020;371:m4654. doi: 10.1136/bmj.m4654 pmid: 33257346

3 Jayasooriya S, Mitchell C, Balen J, Darton TC. Seasonal influenza programme expansion. BM/2020;371:m4713. doi: 10.1136/bmj.m4713 pmid: 33288498

4 Steinfield $\mathrm{R}$. We have so much to gain by getting this vaccination programme right. BMJ Opinion. 4 Dec 2020

https://blogs.bmj.com/bmj/2020/12/04/we-have-so-much-to-gain-by-getting-this-vaccination-programme-right-we-mustnt-jeopardise-it-with-poorcommunication-and-service-models.

5 Binagwaho A, Mathewos K, Kadetz P. A call for equitable distribution of covid-19 vaccines. BMJ Opinion. 2 Dec 2020.

https://blogs.bmj.com/bmi/2020/12/02/a-call-for-equitable-distribution-ofcovid-19-vaccines.

6 Mahase El. Covid-19: Oxford vaccine could be 59\% effective against asymptomatic infections, analysis shows. BMJ 2020;371:m4777doi: 10.1136/bmj.m4777.

7 Doshi P. Pfizer and Moderna's " $95 \%$ effective" vaccines-let's be cautious and first see the full data. BMJ Opinion. 26 Nov 2020

https://blogs.bmj.com/bmj/2020/11/26/peter-doshi-pfizer-and-modernas95-effective-vaccines-lets-be-cautious-and-first-see-the-full-data.

8 Thacker PD. Conflicts of interest among the UK government's covid-19 advisers. BMJ 2020;371:m4716doi: 10.1136/bmj.m4716.

9 McKee M, Nagyova I. Could Slovakia's mass testing programme work in England? BMJ Opinion. 7 Dec 2020.

https://blogs.bmj.com/bmj/2020/12/07/could-slovakias-mass-testing-programme-work-in-england.

10 Wise J. Covid-19: Safety of lateral flow tests questioned after they are found to miss half of cases. BMJ2020;371:m4744

doi: 10.1136/bmi.m4744 pmid: 33277265

11 Gill M. Liverpool's pilot of mass asymptomatic testing for SARS-CoV-2-for what purpose and at what cost? BMJ Opinion. 8 Dec 2020. https://blogs.bmj.com/bmj/2020/12/08/mike-gill-liverpools-pilot-of-massasymptomatic-testing-for-sars-cov-2-for-what-purpose-and-at-what-cost.

12 Feinmann J. The BMJappeal 2020-21: Independent Food Aid Network gives a voice to those determined to make a difference. BMJ 2020;371:m4664 doi: 10.1136/bmj.m4664 pmid: 33268458

13 Moberly T. The charity helping to feed UK families this winter. BMJ 2020;371:m4753doi: 10.1136/bmj.m4753.

This article is made freely available for use in accordance with BMJ's website terms and conditions for the duration of the covid-19 pandemic or until otherwise determined by BMJ. You may use, download and print the article for any lawful, non-commercial purpose (including text and data mining) provided that all copyright notices and trade marks are retained. 